\title{
Lightning Characteristics Over Humid Regions and Arid Regions and Their Association With Aerosols Over Northern India
}

\author{
S. P. Jnanesh, ${ }^{1,2}$ D. M. Lal, ${ }^{1}$ (D) V. Gopalakrishnan, ${ }^{1}$ Sachin D. Ghude, ${ }^{1}$ Sunil D. Pawar, ${ }^{1}$ S. Tiwari, ${ }^{1}$ and \\ ManoJ K. SRivastava ${ }^{2}$
}

\begin{abstract}
The association between aerosol and lightning has been investigated with long-term decadal data (2005-2014) for lightning, aerosol optical depth (AOD), relative humidity, and effective cloud droplet size. To understand the complex relationship between aerosol and lightning, two different regions with different climatic and weather conditions, a humid region R1 $\left(22^{\circ}-\right.$ $\left.29^{\circ} \mathrm{N}, 89^{\circ}-92^{\circ} \mathrm{E}\right)$ and an arid region $\mathrm{R} 2\left(23^{\circ}-28^{\circ} \mathrm{N}, 70^{\circ}-76^{\circ} \mathrm{E}\right)$ of northern India, were chosen for the study domain. The results show that lightning activity was observed to occur more over the humid region $\mathrm{R} 1$, i.e., 1141 days ( $1 / 3$ of total days), than over the arid region $\mathrm{R} 2$, i.e., 740 days ( $1 / 5$ of total days). Also, over the humid region $\mathrm{R} 1$, the highest lightning flash density was recorded as nearly $4.6 \times 10^{-4}$ flashes $/ \mathrm{km}^{2} /$ day observed for 18 days $(1.5 \%)$; on the contrary, over the arid region R2, the maximum lightning flash density was observed to be $2.5 \times 10^{-4}$ flashes $/ \mathrm{km}^{2} /$ day and occurred for about 22 days (2.9\%). The analysis shows that a nonlinear relationship exists between aerosol and lightning with a highly associated influence of relative humidity. A very significant positive and negative co-relation that varies with relative humidity has been observed between AOD and lightning for both humid and arid regions. This shows relative humidity is the key factor in determining the increase or decrease of lightning activity. This study also shows that the larger the cloud droplet size, the higher the relative humidity and vice versa. This study emphasizes that aerosol concentration in the atmosphere influences cloud microphysics by modulating the size of cloud droplets and thereby regulating the lightning frequency. The atmospheric humidity is the driving factor in deciding the positive or negative co-relationship between aerosol and lightning.
\end{abstract}

Keywords: Aerosol optical depth, lightning flash density, effective cloud droplet size, relative humidity, nonlinear relation, positive and negative correlation, humid region, arid region, northern India.

Supplementary Information The online version contains supplementary material available at https://doi.org/10.1007/s00024022-02981-6.

1 Indian Institute of Tropical Meteorology, Pune, India. E-mail: dmlal@tropmet.res.in; dmlalin@gmail.com

2 Department of Geophysics, Banaras Hindu University, Varanasi, India.

\section{Introduction}

Aerosols, directly and indirectly, influence the environment. As a direct effect, aerosols control the solar radiation passing through the atmosphere and regulate the Earth's energy budget (Intergovernmental Panel on Climate Change [IPCC], 2013; Ramanathan et al., 2007). The change in absorption or scattering of solar radiation in the atmosphere determines the temperature of the Earth's atmosphere. Variations in the atmospheric temperature influence almost all of the weather and climate parameters, such as the global climate, precipitation, mesoscale conventions, large-scale circulation, etc. (Bellouin et al., 2005; Haywood \& Boucher, 2000; Hui-jun et al., 2017; Lee et al., 2016; Ramanathan et al., 2001; Wang, 2014). The indirect influence of aerosols in the atmosphere is that their presence modulates the cloud microphysics, alters precipitation rates, and modifies the cloud's convective strength. Furthermore, high hygroscopic aerosol concentration in the atmosphere reduces the cloud droplet size and ultimately leads to inefficient raindrop production or delays raindrop formation (Bréon et al., 2002; Feingold et al., 2003; Kaufman, 2002; Kulmala et al., 2008; Shi et al., 2015; Twomey, 2002). Because of delayed raindrop formation, cloud droplets attain higher altitudes, leading to decreased low-level cloud cover (LCC) and enhanced high-level cloud cover (HCC) (Lal et al., 2013).

Lightning is a convective core phenomenon, and its occurrence depends on factors influenced by aerosol characteristics (Workman et al., 1949; Williams \& Lhermitte, 1983). Surface observations and climate models have suggested that the increase of 
aerosol mass concentration increases the number of lightning flashes (Andreae et al., 2004; Koren et al., 2005; Wang \& Zhou, 2005; Wu et al., 2007; Kulmala et al., 2008; Liao et al., 2011; Chaudhuri, \& Middey, 2013; Tripathi et al., 2017; Gautam et al., 2021). Existing differences in lightning frequency over land and ocean are believed to be the cause of differences in aerosol mass loadings over land and ocean (Williams \& Stanfill, 2002; Zipser, 1994; Yuan et al., 2011). Many studies have suggested that anthropogenic aerosols play a significant role in influencing lightning activity (Antonescu \& Ştefan, 2011; Chaudhuri, \& Middey, 2013; Farias et al., 2009; Kar et al., 2009; Lal \& Pawar, 2011; Orville et al., 2001; Steiger et al., 2002; Steiger \& Orville, 2003; Westcott, 1995; Zhang et al., 2015). Lal and Pawar (2011) suggested that increases in lightning flashes over the cities, away from coastal regions, are mainly due to the in situ aerosol mass availability.

Several studies have reported that aerosol concentration has a strong influence on lightning activity. Since aerosol mass concentrations and their compositions vary widely from region to region, it is difficult to determine the effect of aerosol on lightning activity. For example, over Louisiana, especially near an oil refinery, lightning activity increases with the increase of aerosol concentration (Steiger \& Orville, 2003). But such an increase is not seen for Houston, Texas (Orville et al., 2001; Steiger et al., 2002). Also, many studies on aerosols have reported varying results about the impact of aerosols on precipitation and lightning. As reported by Rosenfeld (1999), an increment in aerosol concentration is generally associated with a decrease in precipitation/ rainfall. However, enhancement of precipitation, with the increase of aerosol concentration in Houston, has been observed and reported by Shepherd and Burian (2003). Similar, varying results have been reported regarding forest fire aerosols and their effect on lightning. For instance, over North America, where enhancement in cloud-to-ground lightning resulting from the intrusion of smoke from fires in Mexico was documented and concluded (Lyons et al., 1998; Murray et al., 2000). However, later studies in Florida showed that the increased positive ground lightning flashes were due to a generation of extraordinary instability over the region (Williams et al.,
2004, 2005). Further, results from a Brazil thunderstorm, which formed due to smoke from biomass burning (Williams et al., 2002), does not validate the results reported for North America (Lyons et al., 1998; Murray et al., 2000). Due to such contradictory results, the key question of how aerosols influence lightning remains unresolved.

Furthermore, aerosols have a strong relation with atmospheric chemistry and greenhouse gases, both of which have an impact on the planet's energy budget. The variation in aerosol influence on atmospheric chemistry and greenhouse gases during the COVID19 pandemic, whose concentration changed over time, is also of interest to researchers (Gautam et al. 2021; Liu et al. 2021).

As discussed above, the catalytic impact of aerosols on clouds is quite complicated. Developing a technique to assess the influence of aerosols on clouds and lightning is challenging. This complex relationship between aerosols and lightning needs to be investigated under a variety of conditions, such as varied degrees of aerosol concentration and lightning frequency. On the basis of the spatiotemporal fluctuation of aerosol loading, lightning occurrence, and two regions with different humidity ranges, the regions $\mathrm{R} 1\left(22^{\circ}-29^{\circ} \mathrm{N}, 89^{\circ}-92^{\circ} \mathrm{E}\right)$ and $\mathrm{R} 2\left(23^{\circ}-28^{\circ}\right.$ $\left.\mathrm{N}, 70^{\circ}-76^{\circ} \mathrm{E}\right)$ over northern India were chosen. R1 covers parts of the Indian states of West Bengal, Assam, Meghalaya and Tripura, and Bangladesh. This region is a humid region with rates of lightning incidence, aerosol loading, and precipitation ranging from 0.06 to 0.14 flashes $/ \mathrm{km} 2 /$ year, 0.6 aerosol optical depth (AOD), and $0.30 \mathrm{~mm} /$ day, respectively. Area R2, on the other hand, covers parts of Gujarat and Rajasthan and is a dry zone with lightning occurrences, aerosol loading, and precipitation rates of 0.04 flashes $/ \mathrm{km}^{2} /$ year, $0.1 \mathrm{AOD}$, and $0.1 \mathrm{~mm} /$ day, respectively. As a result, these areas seemed to be appropriate for the research.

Decadal data for lightning, AOD, relative humidity, and effective cloud droplet size were analyzed to find the relationship between aerosol and lightning over the regions. Nearly 1141 days (more than 3 years, i.e., 1/3 of the days over a total of 10 years) of lightning were observed to occur in the humid region (R1), and 740 days (more than 2 years, 
i.e., $1 / 5$ of total days in 10 years) of lightning occurred in the arid region (R2) during 2005-2014.

\section{Region and Data Details}

\subsection{Geographical Divisions}

Figure 1 shows the climatology of AOD, precipitation rate $\left(\mathrm{mm} /\right.$ day), and lightning flashes $/ \mathrm{km}^{2} /$ year for the years 2005-2014 for the humid region demarcated as R1 $\left(22-29^{\circ} \mathrm{N}, 89-92^{\circ} \mathrm{E}\right)$ and the arid region demarcated as $\mathrm{R} 2\left(23-28^{\circ} \mathrm{N}, 70-76^{\circ} \mathrm{E}\right)$.

Region $\mathrm{R} 1$ is a humid region that receives heavy rainfall, with average rainfall of more than $0.30 \mathrm{~mm} /$ day (Fig. 1b). During the pre-monsoon, especially during April and May, this region experiences thunderstorms with severe lightning, known locally as "nor'westers" or "Kal-Baisakhi," which bring human activities to almost a standstill (Choudhury et al., 2020; Jain et al., 2013; Mahanta et al., 2013). Typically, this region receives 0.06-0.14 lightning flashes $/ \mathrm{km}^{2} /$ year (Fig. 1c), and AOD over the region is measured to be more than 0.6 (Fig. 1a).

Region R2 is an arid region dominated by suspended desert dust particles from the Thar Desert.
The dust particles are generally transported from adjoining Pakistan and the Arabian Peninsula's desert (Lal et al., 2012, 2013; Middleton, 1986; Prospero et al., 2002; Srivastava et al., 2011). The climate in this region is usually dry and hot with very scanty rainfall (less than $0.1 \mathrm{~mm} /$ day). Generally, not much lightning activity (less than 0.04 flashes $/ \mathrm{km}^{2} /$ year) is observed over this region (Fig. 1b, c).

Lightning occurrence is derived from the lightning imaging sensor (LIS) on board the Tropical Rainfall Measuring Mission (TRMM), which provides lightning data with a footprint size of $3.9 \mathrm{~km}$ (nadir) $\times 5.4 \mathrm{~km} \quad$ (limb), field of view $550 \times 550 \mathrm{~km}$, with a detection efficiency of $90 \%$ (Christian et al., 1999). The raw data (science data) from the LIS has been used for the analysis (https:// ghrc.nsstc.nasa.gov/pub/lis/orbit_files/data/science/). The study collected daily lightning data from all 16 ascending and descending orbits of the LIS-TRMM satellites, each with spatial resolution of $550 \times 550 \mathrm{~km}$. The data that fell into our domain region was then isolated and used in the study. The convective precipitation rate data was generated using TRMM satellite sensor 3A12, V-7, which provides worldwide monthly mean surface

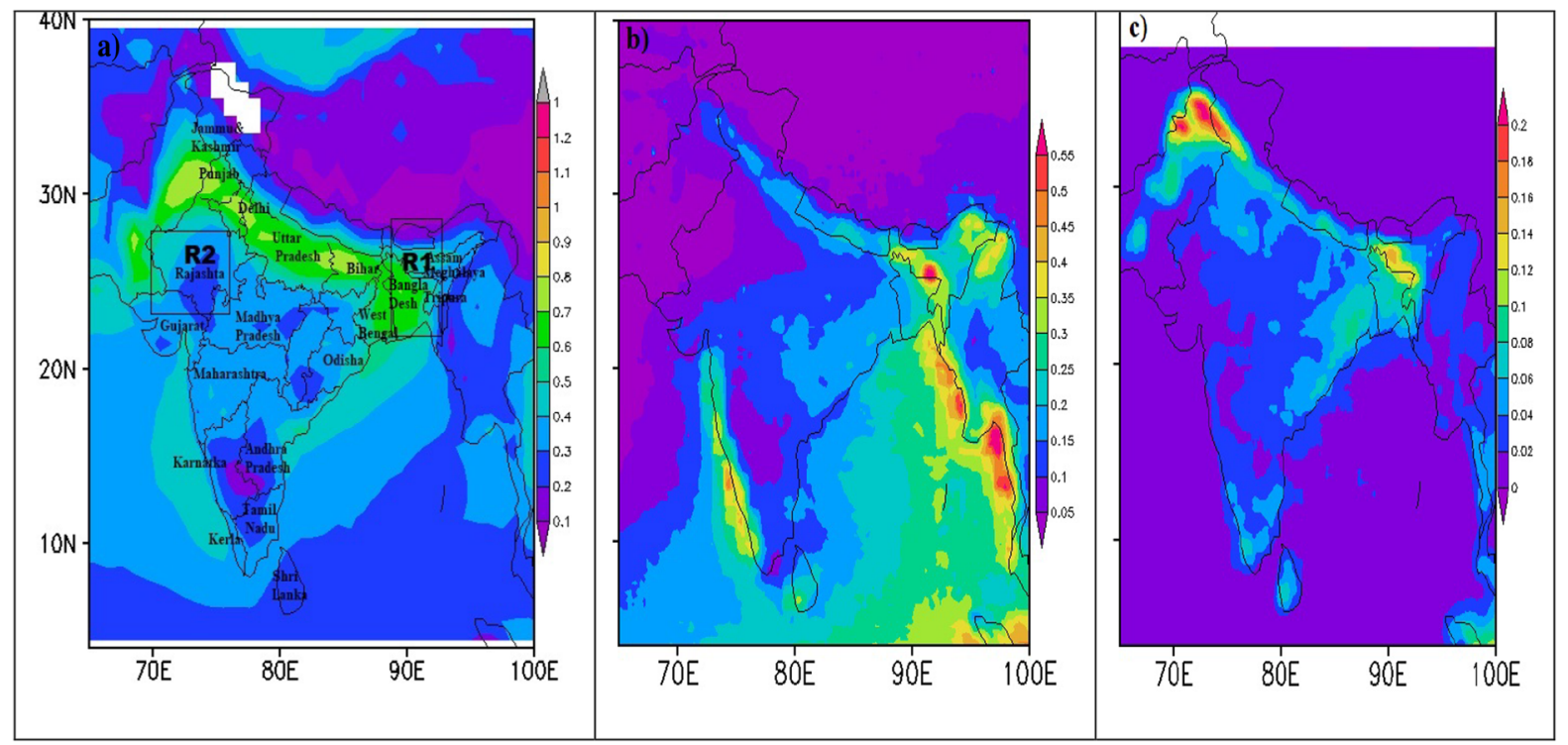

Figure 1

The annual averaged climatology: a aerosol optical depth (AOD), b precipitation rate ( $\mathrm{mm} /$ day), and $\mathbf{c}$ lightning over the study areas R1 and R2 for 2005-2014 
precipitation, rain rates, convective surface precipitation rates, and 28 vertical layers of hydrometeor content on $0.50 \times 0.50$ grid resolution. The AOD and cloud effective particle radius data were obtained from the Moderate Resolution Imaging Spectroradiometer (MODIS) from sensor MYD08_D3 V6.1, Level 3 with grid resolution $1^{\circ} \times 1^{\circ}$. Atmospheric infrared sounder (AIRS) data were used to determine the relative humidity values at $1^{\circ} \times 1^{\circ}$ grid resolution. The AIRS launched in 2002, aboard NASA's Aqua satellite, provides three-dimensional (3D) measurements of temperature, water vapor, trace gases, and surface and cloud properties through the atmospheric column.

In this study, complete lightning data captured by TRMM's LIS during 2005-2014 are considered for analysis. During this period, LIS retrieved 1141 days of lightning in the humid region (R1) and 740 days of lightning in the arid region (R2). Also, AOD data from the MODIS satellite is considered corresponding to the lightning occurrence data. AOD data ranging from less than 0.2 to 2.0 are grouped into 19 bins with a bin size of 0.1 . The AOD of each bin is then added to obtain the mean AOD of the respective bin. Lightning corresponding to each AOD of each bin is similarly added, and mean lightning for each bin is obtained. Mean lightning corresponding to the mean AOD of each bin is considered in the analysis.

\section{Results}

\subsection{Seasonal Variation of Lightning and Aerosol}

Long-term (2005-2014) seasonal variations of the averaged total lightning flashes and AOD for R1 and $\mathrm{R} 2$ are shown in Fig. 2. It is seen from the figure that lightning activity over humid region R1 (Fig. 2a) increases from January to April and then decreases until December. Maximum lightning flashes occur during the pre-monsoon (March-May) and reach their peak in April $\left(\sim 1.06 . \times 10^{-2}\right.$ flashes/ $\mathrm{km}^{2} /$ month). Similar results were also documented in an earlier study for the region (Kandalgaonkar et al., 2010). However, during the decreasing phase, lightning activity increased slightly in AugustSeptember, and then it decreased until December.
As shown in the figure, aerosol concentration over the region shows that the maximum AOD is found in June, and then decreases until October. Minimum AOD $(\sim 0.3)$ is observed in October. The decrease in AOD is due to the drop in aerosol concentration due to the rain scavenging process (Singh et al., 2004) over the region. Over the northeast region (R1), monsoon onset generally occurs during late June (IMD report, 2012), which may be the reason for the observed increase in AOD until June. AOD values increases from October to March that may be attributed to aerosol trapping due to strong subsidence and local biomass burning over the region during the winter period (Dey \& Di Girolamo, 2010; Di Girolamo et al., 2004; Jethva et al., 2005; Kar et al., 2010; Lal et al., 2018). An increase in temperature from March (Fig. S2), combined with the weakening of subsidence and reduction in local biomass burning and thus aerosol concentration, and hence AOD, shows a decreasing trend until May. The average temperature during the winter season (NovFeb) is generally less than $24{ }^{\circ} \mathrm{C}$, but it starts increasing from March $\left(\sim 27^{\circ} \mathrm{C}\right)$ and reaches the maximum in May $\left(\sim 29^{\circ} \mathrm{C}\right)$ over region R1 (Fig. S2). Figure S2 shows seasonally averaged temperature for the humid and arid regions during the year 2005-2014.

On the other hand, monsoon onset is in July in the northwest Indo-Gangetic Plain (IGP) region, including the R2 region (IMD report, 2012). Maximum AOD $(\sim 0.8)$ is observed in July instead of June for the region (Fig. 2b). Aerosol concentration decreases from July to October but shows a slight increase in November. Region R2 is highly linked with desert dust (Lal et al., 2018) due to the presence of the Thar Desert (India) and additional buffing of dust transported from adjoining Pakistan and the Arabian Peninsula's desert (Lal et al., 2012, 2013; Middleton, 1986; Prospero et al., 2002; Srivastava et al., 2011). The dust transportation augments during pre-monsoon over the region (Lau \& Kim, 2006; Lau et al., 2009; Prospero et al., 2002), and hence higher AOD observed during May to July. During the winter season, comparatively less AOD was observed over region $\mathrm{R} 2$ than region $\mathrm{R} 1$. This is attributable to less local biomass burning due to lower population $\left(\sim 200\right.$ persons $/ \mathrm{km}^{2}$ vs. $\sim 1000$ persons $/ \mathrm{km}^{2}$ over 


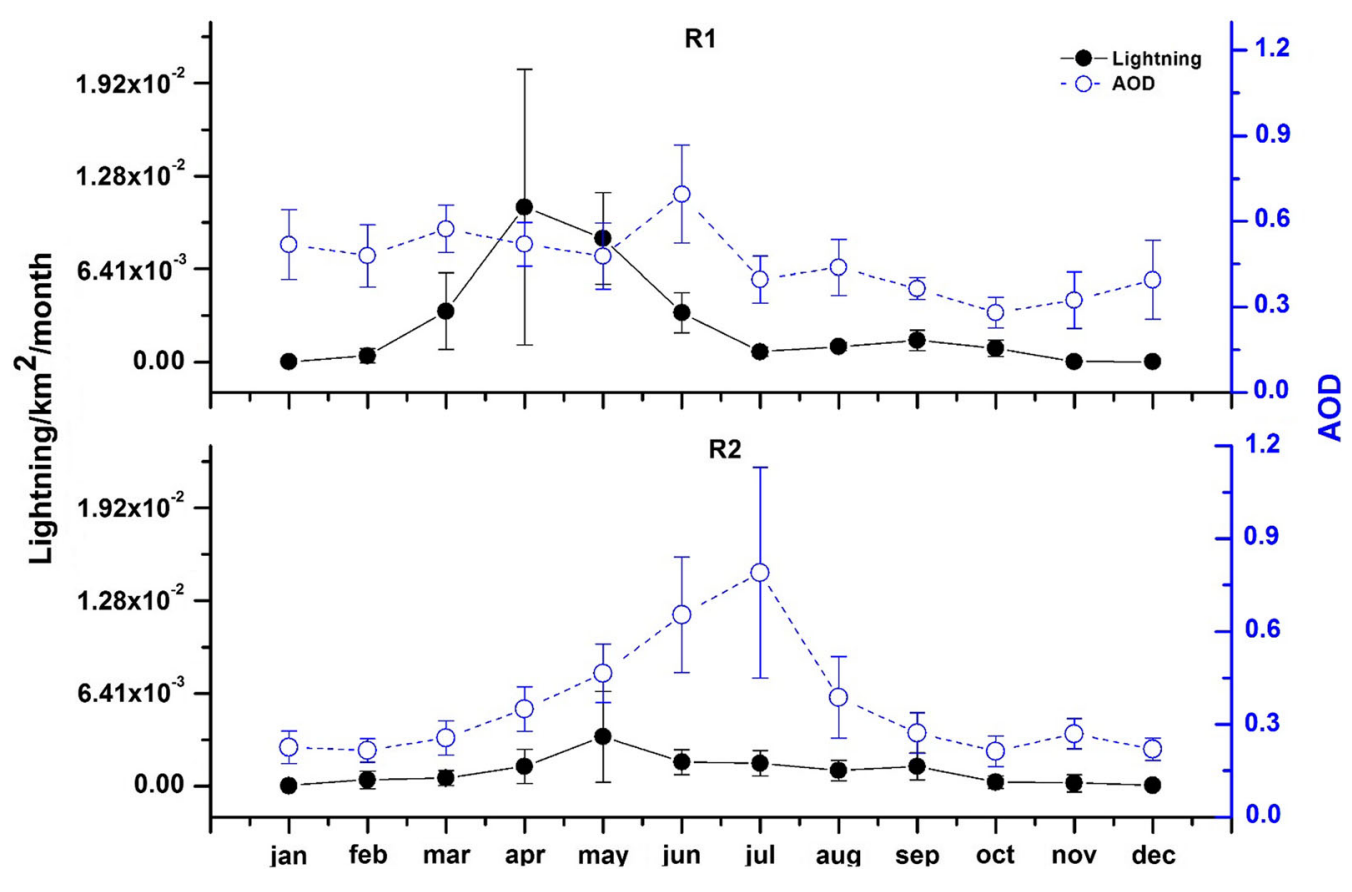

Figure 2

Seasonal variation in lightning flash density (black filled circle) and AOD (blue open circle) during 2005-2014 for a R1 and b R2. Bar is the standard deviation (SD)

R1) and less subsidence due to arid region/climate. The winter temperature (Nov-Feb) over the region is usually more than $30{ }^{\circ} \mathrm{C}$, relatively high compared with the temperature of region $\mathrm{R} 1$ for the entire year (Fig. S2). Over the R2 region, maximum lightning activity is observed in May $\left(3.4 \times 10^{-3}\right.$ flashes/ $\mathrm{km}^{2}$ /month). Similar to the R1 region, over the R2 region, lightning activity decreases from May until December. During the decreasing phase, lightning slightly increases in August-September, as observed over the R1 region, and then it decreases until December. A similar feature was observed by Lal et al. (2018) for the northwestern IGP region.

\subsection{Interannual Variation of Lightning Activity and $A O D$}

Figure 3 shows the averaged interannual variability of total lightning flashes over region R1 for 2005-2014. The figure shows that lightning flash density is decreasing from 2005 to $2014(r=-0.4$, slope $(b)=-6.99$, significant $(p)>95 \%)$, with an exception for the year 2010, where a sudden spike in lightning flash is seen (Fig. 3: R1b). Lightning can be highly associated with convection, resulting in convective rain (Lal \& Pawar, 2009). During this period 2005-2014, decrease in convective rain $(r=-0.15$, $b=-2.17 \mathrm{e}^{-4}, p>95 \%$ ) is also observed for region R1 (Fig. S1). Comparatively, increased convective rain is seen in 2010 when enhanced lightning is observed over the region. In an earlier study, increasing inhibition energy (i.e., decreasing convective available potential energy, CAPE) is reported for the region (Goswami et al., 2010).

The AOD over this region is shown in Fig. 3. The figure shows a clear increase in AOD $(r=0.82$, $b=0.01, p>95 \%$ ) during the period 2005-2014 over region R1 (Fig. 3: R1a). It is interesting to note here that, while lightning shows a decreasing trend, an opposite trend in AOD is observed. However, no trend in annual averaged total lightning is observed over region R2 for the same period $(r=0.06$, $b=1.09, p>95 \%$ ) (Fig. 3: R2b). Convective rainfall is also found to be constant for region R2 (Fig. S1). However, there is a decrease in annual averaged AOD over the region $(r=-0.44$, slope $=$ 

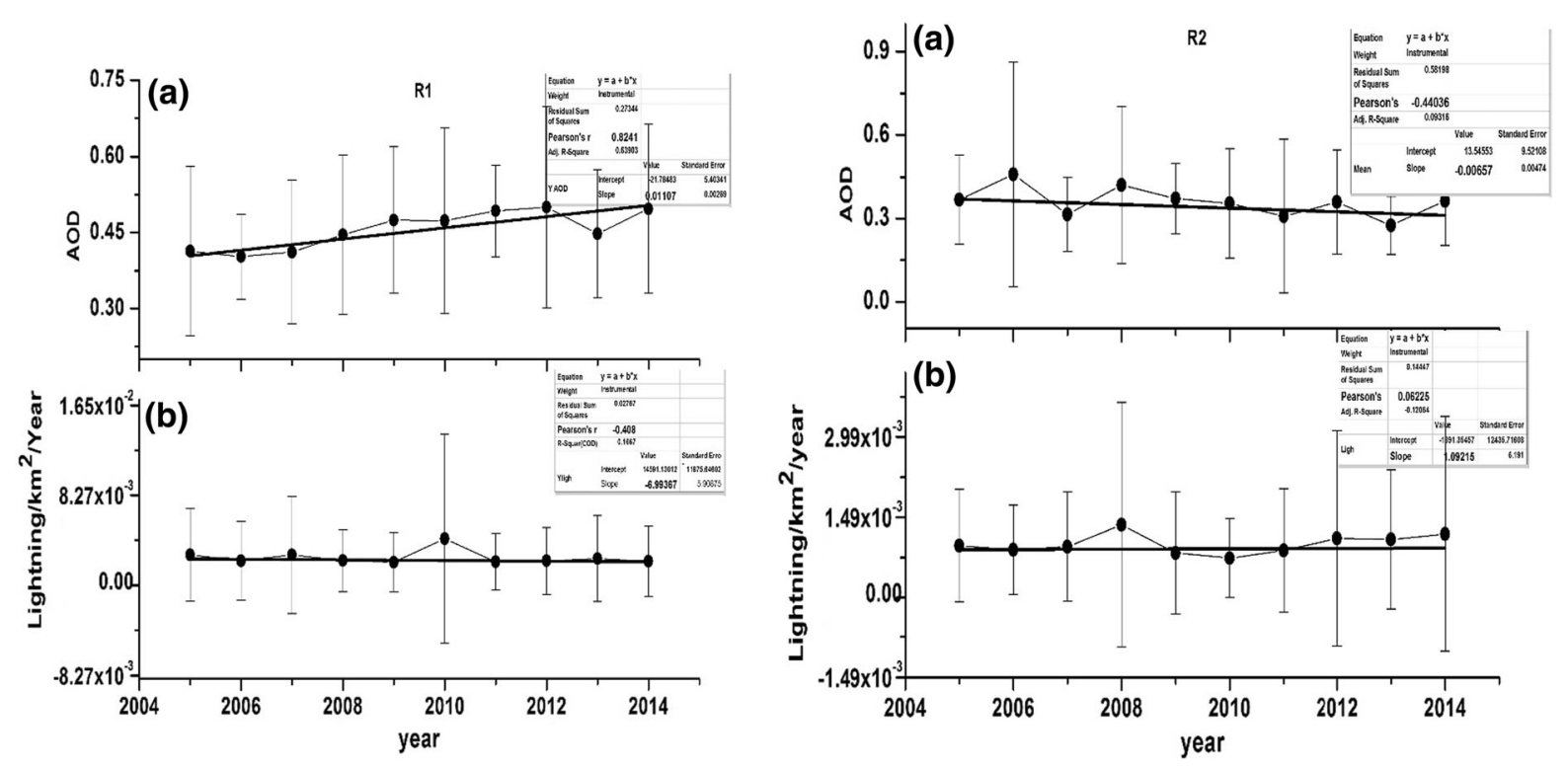

Figure 3

Annual a AOD and b lightning for region R1 and region R2 during 2005-2014. Bar is the standard deviation (SD)

0.006, $p>95 \%$ ) (Fig. 3: R2a). The above finding makes it very difficult to explore the relation between aerosol and lightning on an annual scale. A similar difficulty may arise when using either monthly averaged or daily averaged data of lightning. This is because the ground speed of the TRMM satellite is nearly $6.9 \mathrm{~km} / \mathrm{s}$, and it measures the footprint up to $90 \mathrm{~s}$ when it passes overhead. It is unreasonable to use 90-s data as representative of 1-day lightning data. To overcome this problem, all lightning data, without discrimination of monsoon, pre-monsoon, days, year, etc., has been used to discover the possible relationship between lightning and AOD.

\subsection{Lightning Characteristic Over the Humid and Arid Regions}

As shown in Fig. 4 (R1 and R2), lightning occurred on 1141 days and 740 days, respectively, over humid region R1 and arid region R2 during 2005-2014. The number of lightning days, lightning flash density (flashes $/ \mathrm{km}^{2} /$ day), and AOD for the humid region $\mathrm{R} 1$ are shown in Fig. 4 (R1). The figure shows that nearly 100 days of lightning occurred with flash density of $9.2 \times 10^{-5}$ flashes/ $\mathrm{km}^{2} /$ day when the AOD value was less than 0.2. The number of lightning days and their flash density increase consistently with the increase of AOD over region R1. Lightning occurred for about 219 days with a lightning flash density of approximately $1.5 \times 10^{-4}$ flashes $/ \mathrm{km}^{2} /$ day when AOD was between 0.3 and 0.4 , which is the maximum number of lightning days for humid region $\mathrm{R} 1$. The figure shows that the number of lightning days is falling gradually, whereas its flash density is still increasing. A relatively high lightning flash density of more than $3.5 \times 10^{-4}$ flashes $/ \mathrm{km}^{2} /$ day is experienced for 169 days, 92 days, 58 days, 17 days, and 18 days when AOD values lie between 0.5-0.6, 0.6-0.7, $0.7-0.8,1.1-1.2$, and $1.2-1.3$, respectively. However, on nearly 18 days, lightning occurred with its highest flash density of $4.6 \times 10^{-4}$ flashes $/ \mathrm{km}^{2} /$ day when AOD is 1.2-1.3 over the region. Lightning with flash density of $1.3 \times 10^{-4}$ flashes $/ \mathrm{km}^{2} /$ day when AOD is $1.5-1.6$ over the region is observed for only 2 days, which is the lowest number of lightning days for the region.

From the figure, one can observe that there is no uniform increase in lightning with AOD when the AOD value exceeds 0.6. Whenever AOD is more than 0.6 , lightning flash density fluctuates between $1.3 \times 10^{-4}$ and $4.6 \times 10^{-4}$ flashes $/ \mathrm{km}^{2} /$ day. High- 

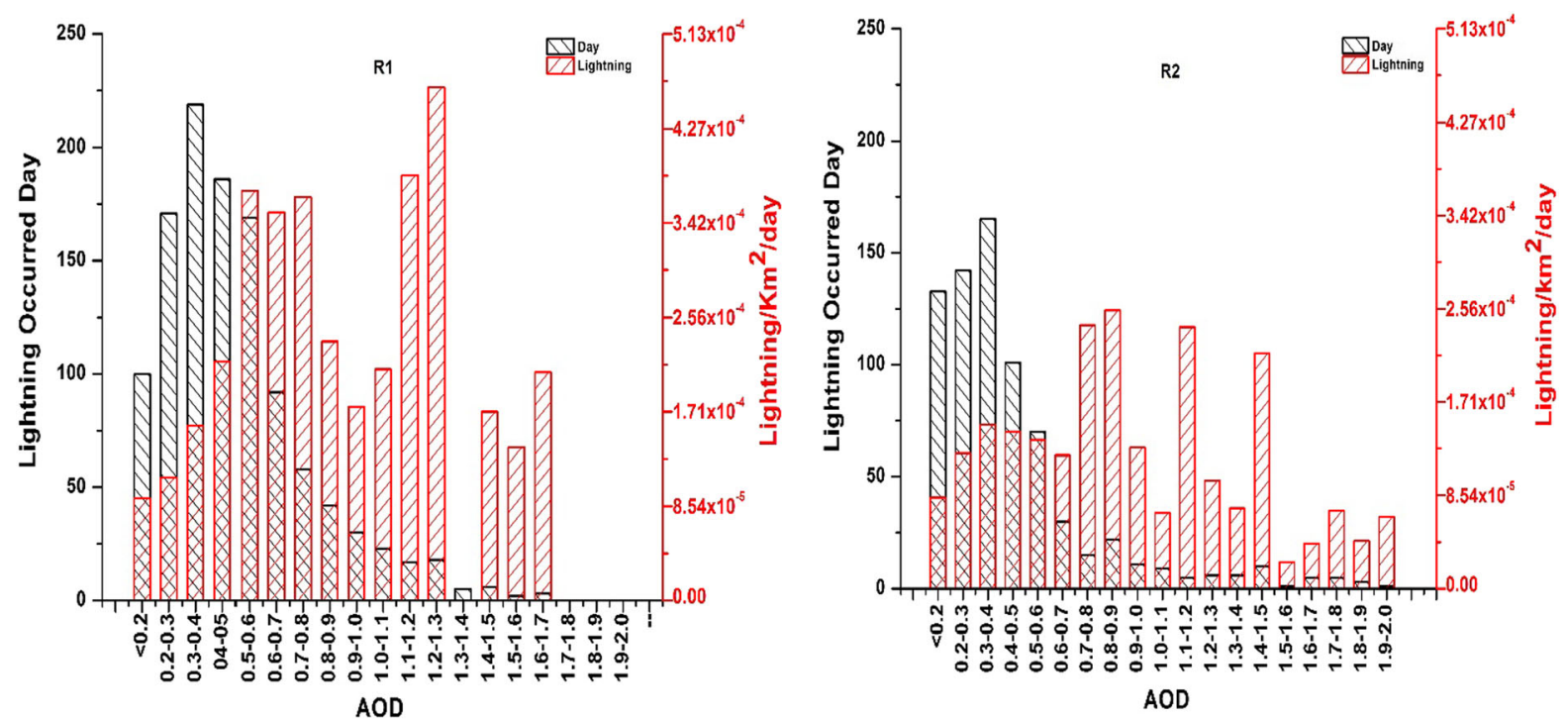

Figure 4

Lightning flash density and number of lightning days for humid region R1 and arid region R2

flash-density lightning is mainly associated with higher AOD, whereas low-flash-density lightning is associated with both high and low AOD. The figure also shows over this region, for most of the days (68\% days), that lightning occurs with flash density less than $3.0 \times 10^{-4}$ flashes $/ \mathrm{km}^{2} /$ day.

A similar feature can be seen for arid region R2 (Fig. 4, R2). Unlike the R1 region, 133 days of lightning with flash density of $8.3 \times 10^{-5}$ flashes/ $\mathrm{km}^{2} /$ day occurred when AOD is less than 0.2 over region $\mathrm{R} 2$. The figure shows that the arid region received 33 days more lightning (with slightly less flash density of $8.3 \times 10^{-5}$ flashes $/ \mathrm{km}^{2} /$ day) in comparison to lightning $\left(9.2 \times 10^{-5}\right.$ flashes $/ \mathrm{km}^{2} /$ day $)$ over humid region R1 (100 days) when AOD is less than 0.2. Similarly, as observed for humid region R1, over the arid region, the number of lightning days and associated flash density increase with increasing of AOD. On 165 days, lightning occurred in the AOD bin range $0.3-0.4$, which is the maximum number of lightning days for the arid region, as compared to 219 days when lightning occurred in the same range bin over region $\mathrm{R} 1$. The point to note here is the lightning flash density for both the regions is nearly the same $\left(1.58 \times 10^{-4}\right.$ flashes $/ \mathrm{km}^{2} /$ day for $\mathrm{R} 1$ and $1.50 \times 10^{-4}$ flashes $/ \mathrm{km}^{2} /$ day for R2) when AOD values lie between 0.3 and 0.4 . However, the number of lightning days over the arid region is considerably less (165 days) than in the humid region (219 days). The number of lightning days drops, and occurrence of 1-day lightning, which is the lowest number of lightning days for arid region $\mathrm{R} 2$, occurred during AOD bin range 1.5-1.6. Flash density is, however, much less $\left(2.3 \times 10^{-5}\right.$ vs. $1.3 \times 10^{-4}$ flashes/ $\mathrm{km}^{2}$ /day) over the arid region versus the humid region during the period. Further, on one occasion, lightning with a lightning flash density of less than $6.5 \times 10^{-5}$ flashes $/ \mathrm{km}^{2} /$ day is observed for just 1 day when AOD is between 1.9 and 2.0. The figure also shows higher lightning flash density of $2.4 \times 10^{-4}$ flashes $/ \mathrm{km}^{2} /$ day, $\quad 2.5 \times 10^{-4} \quad$ flashes $/ \mathrm{km}^{2} /$ day, $2.3 \times 10^{-4}$ flashes $/ \mathrm{km}^{2} /$ day, and $2.1 \times 10^{-4}$ flashes/ $\mathrm{km}^{2} /$ day recorded for $15,22,5$, and 10 days when AOD is $0.7-0.8,0.8-0.9,1.1-1.2$, and 1.4-1.5, respectively. A lightning flash density of $2.5 \times 10^{-4}$ flashes $/ \mathrm{km}^{2} /$ day is the highest lightning flash density for the arid region when AOD is 0.8-0.9. The flash density is almost the same as observed for humid region $\mathrm{R} 1\left(2.3 \times 10^{-4}\right.$ flashes $/ \mathrm{km}^{2} /$ day $)$ during the period. However, it is much less than the highest flash density ( $4.6 \times 10^{-4}$ flashes $/ \mathrm{km}^{2} /$ day) compared to the humid region. Similar to the humid region, the arid region experienced a high flash density of lightning (more than $2.0 \times 10^{-4}$ flashes $/ \mathrm{km}^{2} /$ day for the arid 
region) on comparatively fewer days and lower flash density of lightning (less than $2.0 \times 10^{-4}$ flashes/ $\mathrm{km}^{2} /$ day) most of the days ( $92 \%$ days).

\subsection{Variation of Lightning and AOD Over the Humid and Arid Regions}

The mean of lightning, corresponding to the mean of each AOD bin, for region R1 is shown in Fig. 5. The figure shows lightning flashes consistently increase with AOD from 0.14 to 0.54 for this region (Fig. 5a). Lightning flash density increased from $9.2 \times 10^{-5}$ flashes $/ \mathrm{km}^{2} /$ day for AOD of 0.14 to $3.7 \times 10^{-4}$ flashes $/ \mathrm{km}^{2} /$ day for AOD of 0.54 . A sharp increase $(\sim 300 \%)$ in lightning flash density is seen in the figure. Lightning flash density is almost constant at $3.7 \times 10^{-4}$ flashes $/ \mathrm{km}^{2} /$ day when AOD varies from 0.54 to 0.74 and then decreases until AOD 0.93. At AOD 0.93, lightning flash density sharply jumps to $1.7 \times 10^{-4}$ flashes $/ \mathrm{km}^{2} /$ day. Lightning flash density steadily increases thereafter to $4.6 \times 10^{-4}$ flashes $/ \mathrm{km}^{2} /$ day for AOD 1.25 and then decreases to $1.4 \times 10^{-4}$ flashes $/ \mathrm{km}^{2} /$ day for AOD 1.53 , and then again increases. As seen from Fig. 5b, both positive and negative nonlinear correlations exist between lightning and AOD. A very significant
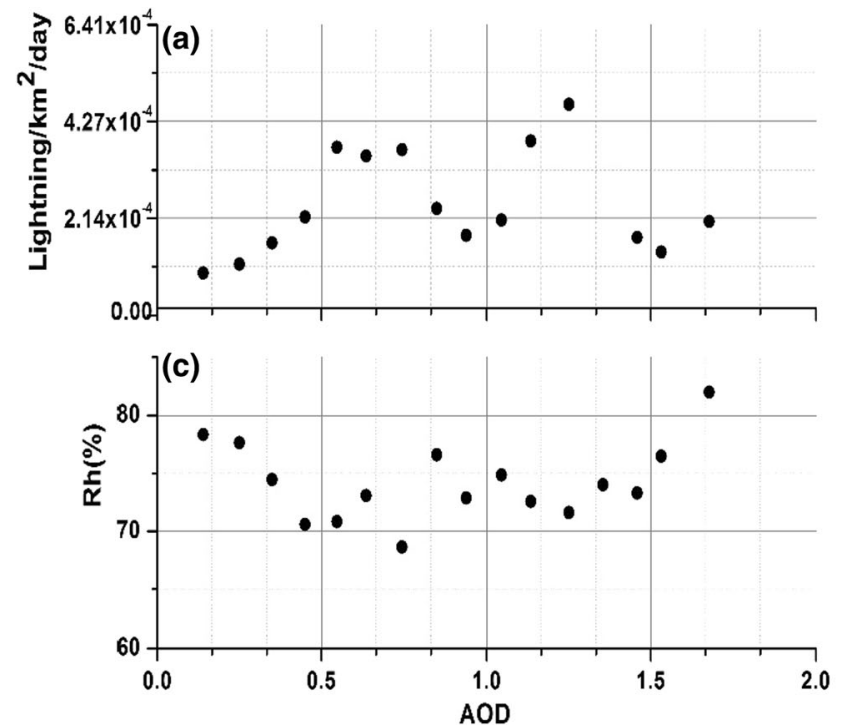

positive correlation $(r=0.94, b=126.96, p>95 \%)$ exists between AOD and lightning for AOD in the range of $0.14-0.54$ and $0.93-1.25 \quad(r=0.96$, $b=234.48, p>95 \%)$; however, a negative correlation is seen for AOD in the range of 0.74-0.93 $(r=0.98, b=-233.11, p>95 \%)$ and $1.25-1.53$ $(r=0.77, b=-152.82, p>95 \%$ ) (Fig. $5 b$ ).

Variation of lightning with AOD for arid region $\mathrm{R} 2$ is plotted in Fig. 6. Like the humid region, the arid region also sees the lightning flash density increase with increasing of AOD, from $8.3 \times 10^{-5}$ flashes $/ \mathrm{km}^{2} /$ day for AOD 0.13 to $1.5 \times 10^{-4}$ flashes/ $\mathrm{km}^{2} /$ day for AOD 0.34. Lightning flash density starts decreasing, reaching $1.2 \times 10^{-4}$ flashes $/ \mathrm{km}^{2} /$ day at AOD 0.65. After that, lightning density again increases and reaches a maximum of $2.5 \times 10^{-4}$ flashes $/ \mathrm{km}^{2} /$ day at AOD 0.84 . After that, lightning flash density steadily decreases with AOD until AOD of 1.04 , when the flash density is $6.9 \times 10^{-5}$ flashes/ $\mathrm{km}^{2} /$ day. Lightning flash density suddenly increases $\left(2.39 \times 10^{-4}\right.$ flashes $/ \mathrm{km}^{2} /$ day $)$ when AOD is 1.15 and then decreases. Within the AOD range of 1.15 and 1.34, lightning flash density decreases from $2.39 \times 10^{-4}$ flashes $/ \mathrm{km}^{2} /$ day to $7.3 \times 10^{-5}$ flashes/ $\mathrm{km}^{2} /$ day. The lowest flash density of $2.3 \times 10^{-5}$ flashes $/ \mathrm{km}^{2} /$ day is observed for an AOD of 1.57 after

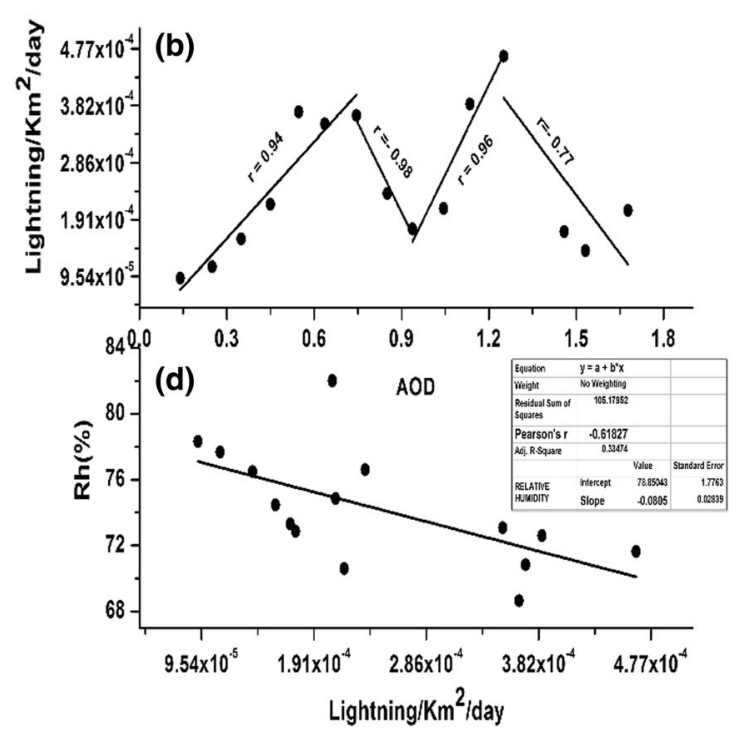

Figure 5

a Lightning flash density. b Correlation between lightning flash density and AOD. c Relative humidity. d Correlation between lightning flash density and relative humidity for the humid region during 2005-2014 

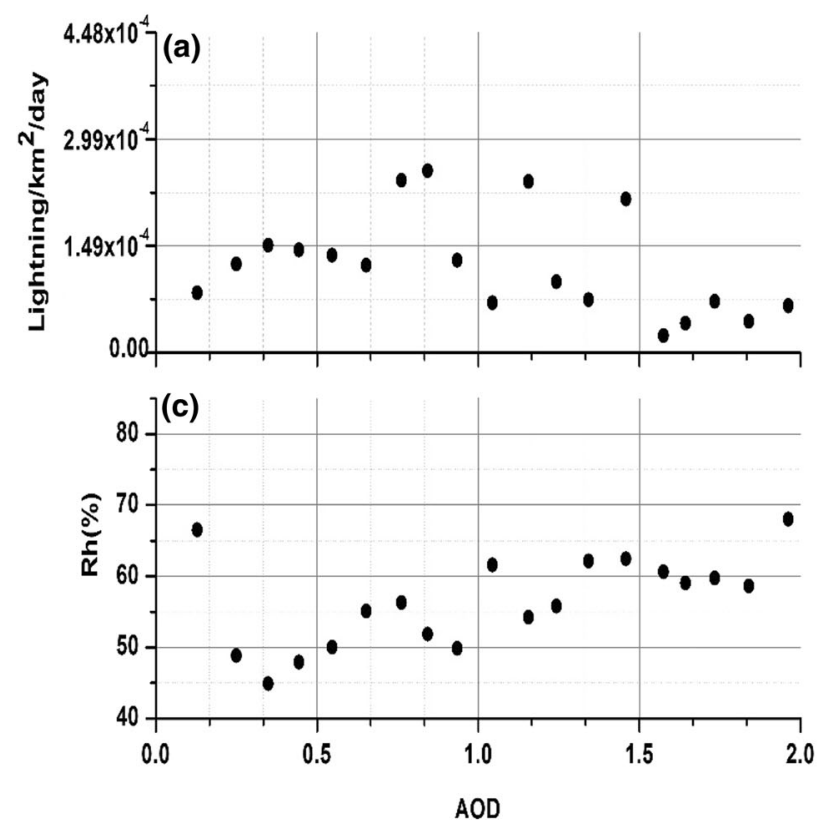

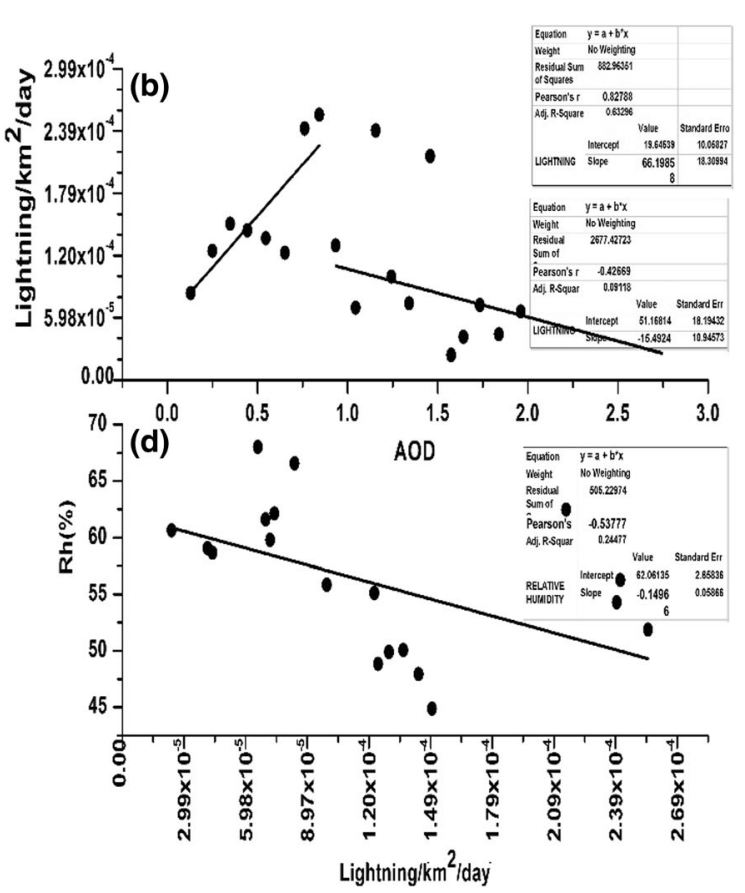

Figure 6

a Lightning flash density. b Correlation between lightning flash density and AOD. c Relative humidity. d Correlation between lightning flash density and relative humidity for the arid region during 2005-2014

a peak of lightning $\left(2.1 \times 10^{-4}\right.$ flashes $/ \mathrm{km}^{2} /$ day $)$ at AOD 1.45. The variation in lightning flash density within the AOD of 1.57-1.96 is the same as seen for the range $0.13-0.65$. However, the flash density of lightning is seen to be less during AOD of 1.57-1.96 than 0.12-0.65. Similar to region R1, a nonlinear relation between lightning and AOD is observed for region $\mathrm{R} 2$. The correlation between lightning and AOD for the R2 region is shown in Fig. 6b. A significant positive correlation between lightning flash density and AOD $(r=0.82, b=66.19$, $p>95 \%$ ) for AOD range $0.12-0.84$ is observed; however, a negative correlation $(r=-0.43$, $b=-15.49, p>95 \%$ ) for AOD range 0.93-1.96 is seen. Both positive and negative relations between lightning and aerosol have been previously documented by many researchers from the entire globe. Aerosols are considered by many studies to be the dominant factor in lightning enhancement (Altaratz et al., 2010; Füllekrug et al., 2002; Lal \& Pawar, 2011; Thornton et al., 2017; Williams \& Stanfill, 2002; Yuan et al., 2011), whereas several studies also have documented suppression of lightning activity due to aerosols (Cheng et al., 2007; Kaufman et al., 2002; Koren et al., 2004, 2008; Li et al., 2017; Siingh et al., 2013, 2014; Tan et al., 2016; Wen et al., 2007, 2008). In their study, Lal et al. (2018) suggested that under low concentration of aerosols, lightning activity increases with the increase of AOD, while during high concentrations of AOD, lightning has been observed to be inhibited over a region of low humidity. Recently, similar results have been reported for central China (Shi et al., 2020), the southern part of India (Dayeh et al., 2021), and other parts of the world (Wang et al., 2018).

Figure $5 \mathrm{c}$ shows the variation of lightning flash density with atmospheric relative humidity and AOD. For the humid region R1, relative humidity decreases for AOD 0.14-0.54, whereas an increase in lightning with AOD is seen (Fig. 5a \& c). A negative relation is revealed between relative humidity and lightning. The figure shows relative humidity is nearly constant for the AOD range of 0.54-0.74, during which lightning density is also found to be constant. A negative relation is also observed between lightning and humidity when humidity is $70.8 \%$ (lightning 
$3.70 \times 10^{-4} \quad$ flashes $/ \mathrm{km}^{2} /$ day), $\quad 73 \%$ (lightning $3.51 \times 10^{-4}$ flashes $/ \mathrm{km}^{2} /$ day), and $68 \%$ (lightning $3.65 \times 10^{-4}$ flashes $/ \mathrm{km}^{2} /$ day), corresponding to AOD values of $0.54,0.63,0.74$, respectively. Relative humidity $(\mathrm{RH})$ suddenly rises to $76 \%$ at AOD 0.85 , and lightning flash density drops to $2.3 \times 10^{-4}$ flashes $/ \mathrm{km}^{2} /$ day. Relative humidity (74\%) starts decreasing from AOD 1.04 until AOD 1.25. At AOD 1.25 , relative humidity is $71 \%$. A steep rise in lightning flash density is observed during this AOD bin range of 1.04-1.25 (Fig. 5a). Relative humidity again increases, while lightning density decreases, up to AOD 1.67. However, during the decreasing phase, lightning density slightly increased at AOD 1.67, but the lightning density is still low. The correlation between relative humidity and lightning for the entire range of AOD 0.13-1.67 is shown in Fig. 5d. A significant negative correlation $(r=-0.61$, $b=-0.08, \quad p>95 \%)$ is seen between relative humidity and lightning flash density. A similar relation is observed for region R2 (Fig. 6c). Minimum flash density $\left(8.3 \times 10^{-5}\right.$ flashes $/ \mathrm{km}^{2} /$ day $)$ is observed for a relative humidity of $66 \%$ and AOD of 0.13 . The relative humidity is seen to fall from $66 \%$ when AOD is 0.13 to $44 \%$ for AOD of 0.34 . Similarly, in region $\mathrm{R} 1$, lightning flash density increases from $8.3 \times 10^{-5}$ flashes $/ \mathrm{km}^{2} /$ day to $1.5 \times 10^{-4}$ flashes $/ \mathrm{km}^{2} /$ day for AOD $0.13-0.34$. Nearly $80 \%$ enhancement in lightning flash density is seen in these AOD range bins. As relative humidity associated with AOD gradually increases from 0.34 to 0.76 , the lightning flash density decreases over the region, except for AOD at 0.76 . Lightning density of $2.4 \times 10^{-4}$ flashes $/ \mathrm{km}^{2} /$ day is observed when AOD is 0.76 . With the decrease in relative humidity from 56 to $49 \%$, AOD increases from 0.76 to 0.93 . A similar inverse relation is observed for relative humidity and lightning flash density for AOD in the range 1.04-1.15. Lightning flash density reaches its minimum of $6.9 \times 10^{-5}$ flashes $/ \mathrm{km}^{2} /$ day when relative humidity is at $61 \%$ (AOD 1.04) and maximum $2.3 \times 10^{-4}$ flashes $/ \mathrm{km}^{2} /$ day at relative humidity $54 \%$ for AOD 1.15. Relative humidity increases from 54 to $62 \%$ when AOD increases from 1.15 to 1.45 and decreases thereafter until AOD is 1.83 (RH 58\%). The maximum relative humidity is at AOD 1.96. The decreasing and increasing lightning during AOD values of $1.15-1.45$ and $1.45-1.83$, respectively, is seen, except for lightning when AOD is 1.45 . Correlation between relative humidity and lightning when AOD is in the range of 0.13-1.96 is shown in Fig. 6d. A significant negative correlation $(r=-0.54, b=-0.14, p>95 \%)$ is also seen over the arid region, similar to humid region R1. A negative correlation between lightning and relative humidity, in addition to a positive correlation between them, is also reported for various part of globe (Yusfiandika et al., 2021). Lal et al. (2013) suggested that atmospheric humidity modulates the effects of aerosols on clouds by changing the cloud characteristics, and ultimately the characteristics of lightning. Usually, high aerosol concentration reduces the cloud droplet size, delays the raindrop formation, and suppresses warm rain clouds. The non-perceptible droplets reaching high altitude (mixed-phase region) augment ice-based cloud electrification in the presence of supercooled water (Jayaratne et al., 1983; Saunders et al., 1991; Takahashi, 1978). Lal et al. (2013) explored the effect of high aerosol concentration in the atmosphere and noted a reduction in low-level cloud cover (LCC) and augmentation of high-level cloud cover (HCC) with the rise of aerosol concentration. They also showed that small cloud droplets resulted in improved convection over the high-aerosol area.

Figure 7 shows the variation of cloud droplet size with AOD and humidity for the R1 region (Fig. 7, $\mathrm{R} 1)$. The effective cloud droplet size, nearly $16 \mu \mathrm{m}$ for AOD 0.14, decreases sharply with the decrease of relative humidity until AOD is 0.54. At AOD 0.54, the effective cloud droplet size was nearly $14 \mu \mathrm{m}$. Within this range of AOD 0.14-0.54, a sharp increase in lightning at about $300 \%$ is observed. A negative correlation of cloud droplet size with lightning, combined with positive correlation of relative humidity, is shown in the figure. Droplet size has increased slightly $(15 \mu \mathrm{m})$ with the increase of relative humidity $(73 \%)$ at AOD 0.63 , and then it has decreased $(14 \mu \mathrm{m})$ with the decrease of relative humidity $(68 \%)$ until AOD of 0.74. An inverse relation of lightning flash density, i.e., $3.51 \times 10^{-4}$ flashes $/ \mathrm{km}^{2} /$ day at AOD 0.63 and $3.65 \times 10^{-4}$ flashes $/ \mathrm{km}^{2} /$ day at AOD 0.74, can be seen in Fig. 5a. Change in droplet size with change in relative humidity along with the 

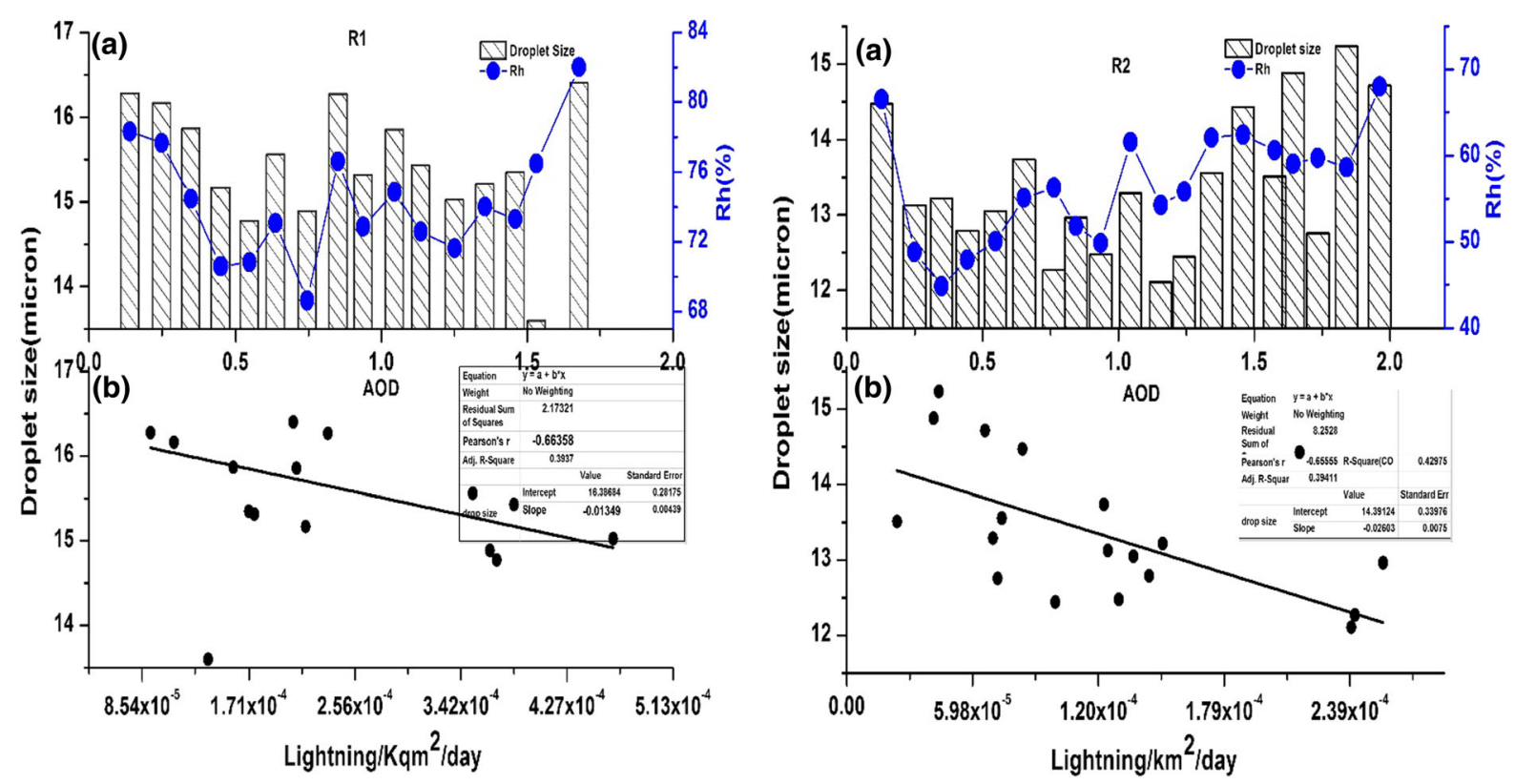

Figure 7

a Droplet size. b Correlation between droplet size and lightning flash density over humid region R1 and arid region R2

change in lightning flash density is observed. A similar relation can be seen for AOD of $0.85,0.93$, and 1.04 with a droplet size of $16.26 \mu \mathrm{m}(\mathrm{RH} 76 \%)$, $15.31 \mu \mathrm{m}$ (RH 72\%), and $15.85 \mu \mathrm{m}$ (RH 74\%), respectively. Droplet size decreasing with increasing AOD from $1.04(15.8 \mu \mathrm{m})$ to $1.25(15.0 \mu \mathrm{m})$ and then increasing until an AOD value of $1.67(16 \mu \mathrm{m})$ is associated with decreasing ( $\mathrm{RH} 74 \%$ to $71 \%$ ) and increasing relative humidity (RH $71 \%$ to $82 \%$ ). The maximum droplet size $(16 \mu \mathrm{m})$ is attained when relative humidity $(82 \%)$ is at AOD 1.67 . During this period, the lightning flash density was comparatively lesser $\left(2.06 \times 10^{-4}\right.$ flashes $/ \mathrm{km}^{2} /$ day $)$, strengthening our observed inverse relationship of cloud droplets with lightning density. A significant negative correlation $(r=-0.66, b=-0.013, p>95 \%)$ is seen between droplet size and lightning flash density, as shown in Fig. 7 (R1b).

A similar relation is observed for the arid region R2, which is shown in Fig. 7 (R2). The effective droplet size is $14.47 \mu \mathrm{m}$ when AOD is 0.13 and relative humidity $66 \%$. Relative humidity of $66 \%$ is relatively high for the arid region. Droplet size decreases with a decrease of the relative humidity as AOD increases from AOD 0.13-0.34 and increases the lightning flash density (Fig. 6a). The opposite trend in droplet size and lightning is also observed for arid region $\mathrm{R} 2$, similar to that observed for humid region $\mathrm{R} 1$. The droplet size started increasing with an increase of relative humidity from AOD 0.34 $(13.21 \mu \mathrm{m})$ to $0.76(13.73 \mu \mathrm{m})$ and decreases with the decrease of relative humidity until AOD is 0.93 $(12.48 \mu \mathrm{m})$, except at AOD 0.76. Decreasing in lightning flash density can be seen for the AOD range 0.34-0.65 (Fig. 6a). At AOD 0.76, while relative humidity is relatively high $(56 \%)$, droplet size is still small, $12.27 \mu \mathrm{m}$, with relatively high lightning flash density $\left(2.4 \times 10^{-4}\right.$ flashes/ $/ \mathrm{km}^{2} /$ day $)$ (Fig. 6a). Results reveal that droplet size is comparatively more sensitive to lightning occurrence than relative humidity. Similar can be seen for AOD 1.04 and 1.15, as droplet size increased $(13.29 \mu \mathrm{m})$, lightning flash density decreased $\left(6.94 \times 10^{-5}\right.$ flashes $/ \mathrm{km}^{2} /$ day $)$, and vice versa (i.e., droplet size $12.10 \mu \mathrm{m}$, lightning flash density $2.3 \times 10^{-4}$ flashes $/ \mathrm{km}^{2} /$ day), respectively. During this period, relative humidity was $61 \%$ for AOD 1.04 and 54\% for AOD 1.15. Droplet size again increases for the AOD range $1.15(12.10 \mu \mathrm{m})$ to 1.34 $(13.55 \mu \mathrm{m})$ with the increase of relative humidity and fall in lightning flash density (Fig. 6a). While relative 
humidity drops from AOD 1.45 to 1.64 , changes in cloud droplet size are not in accordance. But the size of the droplet still follows the inverse lightning relation. As shown in Figs. 6a and 7 (R2a), droplet size suddenly dropped $(12.75 \mu \mathrm{m})$ at AOD 1.73 , with relatively high relative humidity and comparatively high lightning flash density. The largest droplet size $(15.23 \mu \mathrm{m})$ is revealed at AOD 1.8 with nearly high relative humidity (59\%), following the relatively lowest lightning flash density $\left(4.3 \times 10^{-5}\right.$ flashes/ $\mathrm{km}^{2}$ /day). Similar to region $\mathrm{R} 1$, the results of $\mathrm{R} 2$ also show that the droplet size is relatively more sensitive to lightning occurrence than the relative humidity. A more significant negative correlation is found between cloud droplet size and lightning flash density $(r=-0.66, \quad b=-0.026, p>95 \%)$ for the arid region $\mathrm{R} 2$ as found for humid region $\mathrm{R} 1$.

\section{Discussion}

The association between aerosol and lightning is a very complex phenomenon that is still unclear. Many studies have reported varying results suggesting either enhancement or suppression of lightning activity due to aerosol concentration in the atmosphere. To understand this relationship, two homogeneous regions, one humid (R1) and one arid region (R2) of Northern India, were selected, and long-term data from 2005 to 2014 were analyzed. During lightning phenomena, data for AOD, relative humidity, and effective cloud droplet size were analyzed to determine the relationship. It was found that lightning occurred on a total of 1141 days $(\sim 1 / 3$ of the days) over the humid region, and 740 days $(\sim 1 /$ 5 of the days) over the arid region. Results reveal that over humid region R1, on most of the days (68\% days), lightning occurred with flash density less than $3.0 \times 10^{-4}$ flashes $/ \mathrm{km}^{2} /$ day during the low AOD values (up to range $0.3-0.4$ ), whereas lightning flash density greater than $3.0 \times 10^{-4}$ flashes $/ \mathrm{km}^{2} /$ day occurred during higher AOD values, with the highest lightning flash density of $4.6 \times 10^{-4}$ flashes $/ \mathrm{km}^{2} /$ day received during AOD 1.2-1.3. A similar relation was observed for the arid region R2. Lightning flash density greater than $2.0 \times 10^{-4}$ flashes $/ \mathrm{km}^{2} /$ day was observed on comparatively few days ( $8 \%$ of days), whereas nearly $92 \%$ of days experienced lightning with flash density less than $2.0 \times 10^{-4}$ flashes/ $\mathrm{km}^{2} /$ day. Lightning flash density of $2.5 \times 10^{-4}$ flashes $/ \mathrm{km}^{2} /$ day was the highest lightning flash density for the arid region, less than the highest lightning flash density $\left(4.6 \times 10^{-4}\right.$ flashes $/ \mathrm{km}^{2} /$ day $)$ of the humid region. Analysis of the annual variation in the data showed that lightning activity decreased over the humid region and followed the increasing trend of AOD, whereas over the arid region, almost uniform lightning was found with a decreasing trend of AOD. The annual-scale data does not provide conclusive results to demonstrate the relationship between AOD and lightning due to certain satellite data limitations. However, impressive results were obtained after analyzing lightning data when AOD was nearly constant.

For constant bins of AOD, a nonlinear relationship exists between lightning and AOD. Both positive and negative relations have been found, with a highly significant co-relationship (positive relation: $r=0.96, b=234.48, p>95 \%$; negative relation: $r=0.98, b=-233.11, p>95 \%)$. Of note here, the nonlinear relationship between lightning and AOD is strongly associated with atmospheric humidity. An increase in lightning flash density with AOD is associated with a decrease in relative humidity and vice versa. It seems that atmospheric humidity determines the relationship between them by influencing the effects of aerosols on lightning. Similar results have been found for both regions R1 and R2. Lal et al. (2013, 2018) suggested that atmospheric humidity controls the effect of aerosols on clouds as well as lightning. The association between aerosols and atmospheric moisture defines the size of droplets in the atmosphere. At constant humidity, high aerosol concentration in the atmosphere reduces the cloud droplet size (Twomey, 1977). Small cloud droplets reach high altitudes and invigorate the ice-based electrification processes and thus lightning (Rosenfeld, 2006; Williams et al., 2002; Lal et al., 2013, 2014). For both regions, larger cloud droplet size with high humidity during low AOD and vice versa has been found (Fig. 7), which corroborates the aerosol-humidity-cloud droplet size relationship.

Further, the finding of low lightning flash density during the larger size of cloud droplets and high 
lightning flash density during small cloud droplets validates the presence of small cloud droplets at high altitudes, which causes ice-based cloud electrification. Lal et al. (2013) documented larger cloud droplets over a high-humidity area and a smaller size over a low-humidity area. They also documented low convection (low-level cloud cover, LCC) with larger size over the humid region and high convection (high-level cloud cover, HCC) with small cloud droplet size over a low-humidity arid region. A significant negative correlation between lightning and cloud droplet size has been found for both humid region R1 $(r=-0.66, b=-0.013, p>95 \%)$ and arid region $\mathrm{R} 2(r=-0.65, b=-0.02, p>95 \%)$. Also, a significant negative correlation between lightning and relative humidity has been found for both the humid region $(r=-0.61, b=-0.08$, $p>95 \%)$ and arid region $(r=-0.53, b=-0.14$, $p>95 \%)$. The analysis shows that a small change in relative humidity results in a vital change in the droplet size, leading to a change in lightning flash density.

From the above results, we conclude that aerosol concentration in the atmosphere influences cloud microphysics by modulating the size of cloud droplets and thereby regulating the lightning density. The atmospheric humidity is the driving factor in deciding the positive and negative co-relationship between aerosols and lightning.

\section{Summary and Conclusions}

The role of aerosols in the atmosphere and the effect of relative humidity in lightning generation are investigated over the northern Indian region using long-term data from 2005 to 2014. For detailed analysis, and with a desire to understand the complex relationship between aerosols and lightning, two regions with different climatic and weather conditions, a humid region R1 (lat. $22-29^{\circ} \mathrm{N}$, long. $89-92^{\circ}$ E) and an arid region R2 (lat. $23-28^{\circ} \mathrm{N}$, long. $70-76^{\circ}$ E) of northern India, were selected. Decadal data for lightning, AOD, relative humidity, and effective cloud droplet size were analyzed to determine the relationship. The results of the analysis are outlined below:
- Nearly 1141 days ( 1/3 of the days) of lightning occurred over the humid region, and $\sim 740$ days ( $\sim 1 / 5$ of the days) over the arid region during 2005-2014.

- The humid region experienced nearly $68 \%$ of days with lightning flash density of less than $3.0 \times 10^{-4}$ flashes $/ \mathrm{km}^{2} /$ day when AOD was in the range of 0.3-0.4.

- The highest lightning flash density over the humid region was $4.6 \times 10^{-4}$ flashes $/ \mathrm{km}^{2} /$ day when AOD was $1.2-1.3$ for almost 18 days.

- For the arid region, on nearly $92 \%$ of the days, lightning occurred with flash density of less than $2.0 \times 10^{-4}$ flashes $/ \mathrm{km}^{2} /$ day.

- The highest lightning flash density, $2.5 \times 10^{-4}$ flashes $/ \mathrm{km}^{2} /$ day, occurred over the arid region when AOD was 0.8-0.9 for 22 days.

- A nonlinear relationship has been found between lightning and AOD.

- The nonlinear relationship between lightning and AOD is highly associated with relative humidity.

- A very significant positive and negative co-relation was found between lightning and AOD for both humid and arid regions.

- Relative humidity determines the positive or negative relationship between lightning and AOD.

- The larger the cloud droplet size, the higher the relative humidity and vice versa.

- The higher the lightning flash density, the smaller the cloud droplets and vice versa.

- A negative co-relationship between cloud droplet size and lightning flash density is observed, and the same negative relationship is observed between relative humidity and lightning flash density.

These findings emphasize that atmospheric aerosols influence cloud microphysics by modulating the cloud droplet size, whereas the atmospheric humidity decides the positive and negative relation between lightning and AOD.

\section{Acknowledgements}

The authors acknowledge the mission scientists and principal investigators who provided the free data (such as LIS, TRMM, AIRS, and MODIS). The 
authors express thanks to NASA, especially the Goddard Earth Sciences Data and Information Services Center (GES DISC), Giovanni, for providing data for research work. The authors are also thankful to the Director, IITM, for providing all necessary facilities required in the study. ISRO-ARFI and BHU-IoE are also thankful for support of co-author MKS.

Author Contributions DML conceived the study, performed the analysis, and prepared the manuscript. All authors contributed to the study conception and design. Material preparation, data collection, and analysis were performed by SPJ, ST, and MKS. The first draft of the manuscript was written by DML, and all authors commented on previous versions of the manuscript. All authors read and approved the final manuscript.

\section{Funding}

Although the authors' institute is funded by the Ministry of Earth Science, as individuals, the authors of this manuscript did not receive any funding.

\section{Availability of Data and Materials}

In the study, the lightning imaging sensor (LIS) on board the Tropical Rainfall Measuring Mission (TRMM) was used for lightning data, available online from the NASA Global Hydrology Resource Centre, https://doi.org/10.5067/LIS/LIS/DATA201, https://ghrc.nsstc.nasa.gov/hydro/details/lislip. For precipitation rates and convective rain rate data, TRMM satellite sensors 3B43, V-73, and A12, V-7 were used, through NASA Giovanni, which is an online (Web) environment for the display and analysis of geophysical parameters in which the provenance (data lineage) can easily be accessed. Data can be retrieved from https://giovanni.gsfc.nasa. gov/giovanni/. Similarly, aerosol optical depth (AOD) and cloud effective particle radius data were obtained from Moderate Resolution Imaging Spectroradiometer (MODIS), sensor MODIS-Terra ver. 5.1 (MOD08_M3.051) Level 3. Relative humidity $\left(1^{\circ} \times 1^{\circ}\right)$ data were considered from the Atmospheric Infrared Sounder (AIRS). Both are available on NASA Giovanni (https://giovanni.gsfc.nasa.gov/ giovanni/\#service $=$ ArAvTs $\&$ starttime $=2003-01-01 \mathrm{~T}$ 00:00:00Z\&endtime $=2014-12-31 \mathrm{~T} 23: 59: 59 \mathrm{Z} \& \mathrm{bbox}=$ $88,22,96,30 \&$ data=AIRX3STM_006_RelHumid_A(z \%3D925)\%2CAIRX3STM_006_H2OVapMMR_A(z $\% 3$ D500)\&dataKeyword=Humidity\%20\&portal=GI OVANNI\&format.

\section{Declarations}

Conflict of interest The authors declare that they have no competing interests in this section.

Ethical approval The manuscript is not submitted to more than one journal for simultaneous consideration. Submitted work is an original and not published elsewhere in any form or language (partially or in full), and used data is original.

Publisher's Note Springer Nature remains neutral with regard to jurisdictional claims in published maps and institutional affiliations.

\section{REFERENCES}

Altaratz, O., Koren, I., Yair, Y., \& Price, C. (2010). Lightning response to smoke from Amazonian fires. Geophysics Research Letters, 37, 7.

Andreae, M. O., Rosenfeld, D., Artaxo, P., Costa, A. A., Frank, G. P., Longo, K. M., \& Silva-Dias, M. A. F. (2004). Smoking rain clouds over the Amazon. Science, 303, 1337-1342. https://doi. org/10.1126/science.1092779

Antonescu, B., \& Ştefan, S. (2011). The urban effect on the cloudto-ground activity in the Bucharest area Romania. Romanian Reports in Physics, 63-2, 535-542.

Bellouin, N., Boucher, O., Haywood, J., \& Reddy, M. S. (2005). Global estimate of aerosol direct radiative forcing from satellite measurements. Nature, 438, 1138-1141.

Bréon, F. M., Tanré, D., \& Generoso, S. (2002). Aerosol effect on cloud droplet size monitored from satellite. Science, 295, 834-838.

Chaudhuri, S., \& Middey, A. (2013). Effect of meteorological parameters and environmental pollution on thunderstorm and lightning activity over an urban metropolis of India. Urban Climate., 3, 67-75.

Choudhury, B. A., Mahen, K., Hazra, A., Mohan, G. M., Pithani, P., Ghude, S. D., Atri, D., \& Barth, M. C. (2020). A diagnostic study of cloud physics and lightning flash ratesin a severe premonsoon thunderstorm over northeast India. Quarterly Journal Royal Meteorological Society, 146, 1901-1922.

Cheng, C. T., Wang, W. C., \& Chen, J. P. (2007). A modelling study of aerosol impacts on cloud microphysics and radiative properties. Quarterly Journal of the Royal Meteorological Society., 133(623), 283-297.

Christian H J (1999) The lightning Imaging Sensor. Procedgs.11th IntI.conf. on Atmos. Elec.,Guntersville, AL, ICAE. 746-749. 
Dayeh, M. A., Ashraf, F., Haifa, I.-A., \& Abdelgadir, A. (2021). Effects of aerosols on lightning activity over the Arabian Peninsula. Atmospheric Research. https://doi.org/10.1016/j. atmosres.2021.105723

Dey, S., \& Di Girolamo, L. (2010). A climatology of aerosol optical and microphysical properties over the Indian subcontinent from 9 years (2000-2008) of Multiangle Imaging Spectroradiometer (MISR) data. Journal of Geophysical Research, 115, D15204. https://doi.org/10.1029/2009JD013395

Di Girolamo, L., Bond, T. C., Bramer, D., Diner, D. J., Fettinger, F., Kahn, R. A., Martonchik, J. V., Ramana, M. V., Ramanathan, V., \& Rasch, P. J. (2004). Analysis of multi-angle imaging spectro-radiometer (MISR) aerosol optical depths over greater India during winter 2001-2004. Geophysical Research Letters, 31, L23115. https://doi.org/10.1029/2004GL021273

Farias, W. R. G., Pinto, O., Jr., Naccarato, K. P., \& Pinto, I. R. C. A. (2009). Anomalous lightning activity over the Metropolitan Region of São Paulo due to urban effects. Atmospheric Research, 91, 485-490.

Feingold, G., Eberhard, W. L., Veron, D. E., \& Previdi, M. (2003). First measurements of the Twomey indirect effect using groundbased remote sensors. Geophysical Research Letters, 30(6), 1287. https://doi.org/10.1029/2002GL016633

Füllekrug, M., Price, C., Yair, Y., \& Williams, E. R. (2002). Intense oceanic lightning. Annales Geophysicae, 20(20), 133-137.

Gautam, S., Gautam, A. S., Singh, K., James, E. J., \& Brema, J. (2021). Investigations on the relationship among lightning, aerosol concentration, and meteorological parameters with specific reference to the wet and hot humid tropical zone of the southern parts of India. Environmental Technology and Innovation, 22, 414.

Gautam, A. S., Kumar, S., Gautam, S., Anand, A., Kumar, R., Joshi, A., Bauddh, K., \& Singh, K. (2020). Pandemic induced lockdown as a boon to the environment: Trends in air pollution concentration across India. Asia-Pacific Journal of Atmospheric Sciences. https://doi.org/10.1007/s13143-021-00232-7

Goswami, B. B., Mukhopadhyay, P., Mahanta, R., \& Goswami, B. N. (2010). Multiscale interaction with topography and extreme rainfall events in the northeast Indian region. Journal of Geophysical Research Atmospheres, 115(12), 1. https://doi.org/10. 1029/2009JD012275

Haywood, J., \& Boucher, O. (2000). Estimates of the direct and indirect radiative forcing due to tropospheric aerosols: A review. Reviews of Geophysics, 38, 513-543.

Hui-Jun, W., Huo-Po, C., Jiping, L., Hui-Jun, W., Huo-Po, C., \& Liu, J. (2017). Arctic sea ice decline intensified haze pollution in Eastern China Arctic sea ice decline intensified haze pollution in Eastern China. Atmospheric and Oceanic Science Letter, 1, 2834. https://doi.org/10.3878/AOSL20140081

Indian Meteorological Department report (2012) Synoptic Meteorology 13/2013, Government of India

IPCC, Climate Change (2013) The Physical Science Basis, chapter 2, Cambridge University Press, Cambridge, UK, Contribution of Working Group I to the Fourth Assessment Report of the Intergovernmental Panel on Climate Change.

Jain, S. K., Kumarb, V., \& Sahariad, M. (2013). Analysis of rainfall and temperature trends in northeast India. International Journal of Climatology, 33, 968-978.

Jayaratne, E. R., Saunders, C. P. R., \& Hallett, J. (1983). Laboratory studies of the charging of soft-hail during ice crystal interactions. Quarterly Journal of the Royal Meteorological Society, 109(461), 609-630. https://doi.org/10.1002/qj. 49710946111

Jethva, H., Satheesh, S. K., \& Srinivasan, J. (2005). Seasonal variability of aerosols over the Indo-Gangetic Plains. Journal of Geophysical Research, 110, D21204. https://doi.org/10.1029/ 2005JD005938

Kandalgaonkar, S. S., Tinmaker, M. I. R., \& Vani, G. (2010). A lightning climatology of Northeast india: 1998-2007. The International Journal of Meteorology, 01, 35.

Kar, S. K., Liou, Y. A., \& Ha, K. J. (2009). Aerosol effects on the enhancement of cloud-to-ground lightning over major urban areas of South Korea. Atmospheric Research, 92, 80-87.

Kar, J., Deeter, M. N., Fishman, J., Liu, Z., Omar, A., Creilson, J. K., Trepte, C. R., Vaughan, M. A., \& Winker, D. M. (2010). Wintertime pollution over the Eastern Indo-Gangetic Plains as observed from MOPITT, CALIPSO and tropospheric ozone residual data. Atmospheric Chemistry and Physics, 10, 12273-12283.

Kaufman, Y. J. (2002). The effect of smoke particles on clouds and climate forcing. Science, 277(5332), 1636-1639. https://doi.org/ 10.1126/science.277.5332.1636

Kaufman, Y. J., Tanré, D., Holben, B. N., Mattoo, S., Remer, L. A., \& Eck, T. F. (2002). Aerosol radiative impact on spectral solar flux at the surface, derived from principal-plane sky measurements. Journal of the Atmospheric Sciences, 59(3), 635-646.

Koren, I., Kaufman, Y. J., Remer, L. A., \& Martins, J. V. (2004). Measurement of the effect of Amazon smoke on inhibition of cloud formation. Science, 303(5662), 1342-1345.

Koren, I., Kaufman, Y. J., Rosenfeld, D., Remer, L. A., \& Rudich, Y. (2005). Aerosol invigoration and restructuring of Atlantic convective clouds. Journal of Geophysical Research Letters, 32, L14828. https://doi.org/10.1029/2005GL023187

Koren, I., Martins, J. V., Remer, L. A., \& Afargan, H. (2008). Smoke invigoration versus inhibition of clouds over the Amazon. Science, 321(5891), 946-949.

Kulmala, M., Raga, G. B., Lohmann, U., Reissell, A., Andreae, M. O., O'Dowd, C. D., Rosenfeld, D., \& Fuzzi, S. (2008). Flood or drought: How do aerosols affect precipitation? Science. https:// doi.org/10.1126/science. 1160606

Lal, D. M., \& Pawar, S. D. (2009). Relationship between rainfall and lightning over central Indian region in monsoon and premonsoon seasons. Atmospheric Research, 92(4), 402-410.

Lal, D. M., \& Pawar, S. D. (2011). Effect of urbanization on lightning over four metropolitan cities of India. Atmospheric Environment, 45, 191-196.

Lal, D. M., Ghude, S. D., Patil, S. D., Kulkarni, S. H., Jena, C., Tiwari, S., \& Srivastav, M. K. (2012). Tropospheric ozone and aerosol long-term trends over the Indo-Gangetic Plain (IGP) region, India. Atmospheric Research, 116, 82-92.

Lal, D. M., Patil, S. D., Singh, H. N., Ghude, S. D., Tiwari, S., \& Srivastava, M. K. (2013). Influence of aerosol on clouds over the Indo-Gangetic Plain, India. Climate Dynamics, 41, 601-612. https://doi.org/10.1007/s00382-013-1775-Z

Lal, D. M., Gude, S., Sing, J., \& Tiwari, S. (2014). Relationship between size of cloud ice and lightning in the tropics. Advances in Meteorology. https://doi.org/10.1155/2014/471864

Lal, D. M., Gude, S., Mahakur, M., Waghmare, R. T., Tiwari, S., Srivastava, M. K., Meena, G. S., \& Chate, D. M. (2018). Relationship between aerosol and lightning over Indo-GangeticPlain 
(IGP). Climate Dynamics. https://doi.org/10.1007/s00382-0173851-2

Lau, K. M., Kim, K. M., Hsu, C. N., \& Holben, B. N. (2009). Possible influences of air pollution, dustand sandstorms on the Indian monsoon. WMO Bulletien, 58, 22-30.

Lau, K. M., \& Kim, K. M. (2006). Observational relationships between aerosol and Asian monsoon rainfall, and circulation. Geophysical Research Letters, 33, L21810. https://doi.org/10. 1029/2006GL027546

Lee, S.-S., Ming, Y., Qian, Y., Xu, X., Zhao, C., Takemura, T., Zhang, F., Rosenfeld, D., Li, Z., Wang, K., Liu, J., Manoj, M. G., \& Huang, J. (2016). Aerosol and monsoon climate interactions over Asia. Reviews of Geophysics, 54(4), 866-929. https://doi. org/10.1002/2015rg000500

Li, Z., Guo, J., Ding, A., Liao, H., \& Zhu, B. (2017). Aerosol and boundary-layer interactions and impact on air quality. National Science Review, 6, 810-833.

Liao, F., Meng, W., Wan, Q., Zhang, R., Wang, Y., \& Tan, H. (2011). Long-term impacts of aerosols on precipitation and lightning over the Pearl River Delta megacity area in China. Atmospheric Chemistry and Physics, 11(23), 12421-12436. https://doi.org/10.5194/acp-11-12421-2011

Liu, et al. (2021). Near-real-time monitoring of global $\mathrm{CO}_{2}$ emissions reveals the effects of the COVID-19 pandemic. Natural Communication, 11, 5172. https://doi.org/10.1038/s41467-02018922-7

Lyons, W. A., Nelson, T. E., Williams, E. R., Cramer, J., \& Turner, T. (1998). Enhanced positive cloud-to-ground lightning in thunderstorms ingesting smoke. Science, 282, 77-81.

Mahanta, R., Sarma, D., \& Choudhury, A. (2013). Heavy rainfall occurrences in northeast India. International Journal of Climatology, 33, 1456-1469.

Middleton, N. J. (1986). A geography of dust storms in southwest Asia. International Journal of Climatology, 6, 183-196. https:// doi.org/10.1002/joc.3370060207

Murray, N. D., Orville, R. E., \& Huffines, G. R. (2000). Effect of pollution from Central American fires on cloud-to-ground lightning in May 1998. Geophysical Research Letters, 27(15), 2249. https://doi.org/10.1029/2000GL011656

Orville, R. E., Huffine, G., Gammon, J. N., Zhang, R., Phillips, S., Allen, S., \& Read, W. (2001). Enhancement of cloud-to-ground lightning over Houston Texas. Geophysical Research Letters, 28(13), 2597-2600.

Prospero, J. M., Ginoux, P., Torres, O., Nicholson, S. E., \& Gill, T. E. (2002). Environmental characterization of global sources of atmospheric soil dust identified with the Nimbus 7 Total Ozone Mapping Spectrometer (TOMS) absorbing aerosol product. Reviews of Geophysics, 40(1), 1. https://doi.org/10.1029/ 2000RG000095

Ramanathan, V., Crutzen, P. J., Kiehl, J. T., \& Rosenfeld, D. (2001). Aerosols, climate, and the hydrological cycle. Science, 294(5549), 2119-2124.

Ramanathan, V., Li, F., Ramana, M. V., Praveen, P. S., Kim, D., Corrigan, C. E., Nguyen, H., Stone, E. A., Schauer, J. J., Carmichae, G. R., Adhikary, B., \& Yoon, S. C. (2007). Atmospheric brown clouds: hemispherical and regional variations in long range transport, absorption, and radiative forcing. Journal of Geophysical Research, 112(22), 1.

Rosenfeld, D. (1999). TRMM observed first direct evidence of smoke from forest fires inhibiting rainfall. Geophysical Research Letters, 26, 3105-3108.
Rosenfeld, D. (2006). Aerosol-cloud interactions control of earth radiation and latent heat release budgets. Space Science Reviews, 125(1-4), 149-157.

Saunders, C. P. R., Keith, W. D., \& Mitzeva, R. P. (1991). The effect of liquid water on thunderstorm charging. Journal of Geophysical Research, 96(D6), 1. https://doi.org/10.1029/ $91 \mathrm{jd} 00970$

Shepherd, J. M., \& Burian, S. J. (2003). Detection of urban-induced rainfall anomalies in a major coastal city. Earth Interactions, 7(4). $\quad$ https://doi.org/10.1175/1087-3562(2003)007<0001: douira $>2.0 . \operatorname{co} ; 2$.

Shi, Z., Tan, Y. B., Tang, H. Q., Sun, J., Yang, Y., Peng, L., \& Guo, X. F. (2015). Aerosol effect on the land-ocean contrast in thunderstorm electrification and lightning frequency. Atmospheric Research, 164-165, 131-141.

Shi, Z., Wang, H. C., Tan, Y. B., Li, L. Y., \& Li, C. S. (2020). Influence of aerosols on lightning activities in central eastern parts of China. Atmospheric Science Letters, 21(2), 1. https://doi. org/10.1002/asl.957

Siingh, D., Buchunde, P. S., Singh, R. P., Nath, A., Kumar, S., \& Ghodpage, R. N. (2014). Lightning and convective rain study in different parts of India. Atmospheric Research, 137, 35-48.

Siingh, D., Kumar, P. R., Kulkarni, M. N., Singh, R. P., \& Singh, A. K. (2013). Lightning, convective rain and solar activityOver the south/southeast Asia. Atmospheric Research, 120-121, 99-111.

Singh, R. P., Dey, S., Tripathi, S. N., Tare, V., \& Holben, B. (2004). Variability of aerosol parameters over Kanpur, northern India. Journal of Geophysical Research, 109, D23206. https:// doi.org/10.1029/2004JD004966

Srivastava, S. K., Srivastava, M. K., Saha, A., Tiwari, S., Singh, S., Dumka, U. C., et al. (2011). Aerosol optical properties over delhi and manora peak during a rare dust event in early April 2005. International Journal of Remote Sensing, 32, 7939-7954.

Steiger, S. M., Orville, R. E., \& Huffines, G. (2002). Cloud-to ground lightning characteristics over Houston Texas: 1989-2000. Journal of Geophysical Research Atmospheres, 107(D11), 2-13.

Steiger, S. M., \& Orville, R. E. (2003). Cloud-to-ground lightning enhancement over southern Louisiana. Geophysical Research Letters, 30(19), 1975. https://doi.org/10.1029/2003GL017923

Takahashi, T. (1978). Riming electrification as a charge generation mechanism in thunderstorms. Journal of Atmospheric Science, 35, 1536-1548.

Tan, Y. B., Peng, L., Shi, Z., \& Chen, H. R. (2016). Lightning flash density in relation to aerosol over Nanjing (China). Atmospheric Research, 174, 1-8. https://doi.org/10.1016/j.atmosres.2016.01. 009

Thornton, J. A., Virts, K. S., Holzworth, R. H., \& Mitchell, T. P. (2017). Lightning enhancement over major oceanic shipping lanes. Geophysical Research Letters, 44(17), 9102-9111.

Tripathi, S. N., Pai, D. S., Koren, I., Kanawade, V. P., \& Sarangi, C. (2017). Investigation of the aerosol-cloud-rainfall association over the Indian summer monsoon region. Atmospheric Chemistry and Physics, 17(8), 5185-5204. https://doi.org/10.5194/acp-175185-2017

Twomey, S. (2002). The influence of pollution on the shortwave albedo of clouds. Journal of the Atmospheric Sciences, 34(7), 1149-1152. https://doi.org/10.1175/1520-0469

Twomey, S. (1977). The influence of pollution on the shortwave albedo of clouds. Journal of the Atmospheric Sciences, 34(7), 
1149-1152. https://doi.org/10.1175/1520-0469(1977)034\% 3c1149:tiopot\%3e2.0.co;2

Wang, K. C. (2014). Measurement biases explain discrepancies between the observed and simulated decadal variability of surface incident solar radiation. Science and Reports, 4, 6144. https://doi.org/10.1038/srep06144

Wang, Y., \& Zhou, L. (2005). Observed trends in extreme precipitation events in China during 1961-2001 and the associated changes in large-scale circulation. Geophysical Research Letters, 32, L09707. https://doi.org/10.1029/2005GL022574

Wang, Q., Li, Z., Guo, J., Zhao, C., \& Cribb, M. (2018). The climate impact of aerosols on the lightning flash rate: Is it detectable from long-term measurements? Atmospheric Chemistry and Physics, 18(17), 12797-12816. https://doi.org/10.5194/ acp-18-12797-2018

Wen, G., Marshak, A., \& Cahalan, R. F. (2008). Importance of molecular Rayleigh scattering in the enhancement of clear sky reflectance in the vicinity of boundary layer cumulus clouds. Journal of Geophysical Research Atmospheres, 113(D24), 1. https://doi.org/10.1029/2008JD010592

Wen, G., Marshak, A., Cahalan, R. F., Remer, L. A., \& Kleidman, R. G. (2007). 3-d aerosol-cloud radiative interaction observed in collocated MODIS and ASTER images of cumulus cloud fields. Journal of Geophysical Research Atmospheres, 112(D13), 1. https://doi.org/10.1029/2006JD008267

Westcott, N. E. (1995). Summertime cloud-to-ground lightning activity around major Midwestern urban areas. Journal of Applied Meteorology, 34, 1633-1642.

Williams, E. R., \& Lhermitte, R. M. (1983). Radar tests of the precipitation hypothesis for thunderstorm electrification. Journal of Geophysical Research: Oceans, 88(C15), 10984-10992.

Williams, E., \& Stanfill, S. (2002). The physical origin of the land ocean contrast in lightning activity. Comptes Rendus De L'académie Des Sciences, 3, 1277-1292.
Williams, E. R., et al. (2002). Contrasting convective regimes over the Amazon: Implications for cloud electrification. Journal of Geophysical Research, 107(D20), 8082.

Williams, E., Chan, T., \& Boccippio, D. (2004). Islands as miniature continents: Another look at the land-ocean lightning contrast. Journal of Geophysical Research, 109, D16206.

Williams, E. R., Mushtak, V. C., Rosenfeld, D., Goodman, S. J., \& Boccippio, D. J. (2005). Thermodynamic conditions favorable to superlative thunderstorm updraft, mixed phase microphysics and lightning flash rate. Atmospheric Research, 76, 288-306.

Workman, E. J., \& Reynolds, S. E. (1949). Electrical activity as related to thunderstorm cell growth. Bulletin of the American Meteorological Society., 30, 142-149.

Wu, D. L., Molina, M. J., Li, G., Zhang, R., \& Fan, J. (2007). Intensification of Pacific storm track linked to Asian pollution. Proceedings of the National Academy of Sciences, 104(13), 5295-5299. https://doi.org/10.1073/pnas.0700618104

Yusfiandika, F., Lim, S. C., Gomes, C., Chockalingam, A., \& Pay, L. C. (2021). Lightning behaviour during the COVID-19 Pandemic. F1000Research. https://doi.org/10.12688/f1000research. 70650.3

Yuan, T., Remer, L. A., Pickering, K. E., \& Yu, H. (2011). Observational evidence of aerosol enhancement of lightning activity and convective invigoration. Geophysical Research Letters, 38, L04701. https://doi.org/10.1029/2010GL046052

Zhang, H., Zhou, C., Wang, Z., Zhao, S., \& Li, J. (2015). The influence of different black carbon and sulfate mixing methods on their optical and radiative properties. Journal of Quantitative Spectroscopy and Radiative Transfer, 161, 105-116. https://doi. org/10.1016/j.jqsrt.2015.04.002

Zipser, E. J. (1994). Deep cumulonimbus cloud systems in the tropics with and without lightning. Monthly Weather Review, 122(8), 1837-1851. https://doi.org/10.1175/1520-0493 